\title{
Özel Yetenekli Öğrencilerin Mühendislik Algılarının Çiz-Yaz-Anlat Tekniği Kullanılarak İncelenmesi
}

\author{
Oğuzhan Nacaroğlu ${ }^{* 1}$ ve Mehmet Arslan ${ }^{2}$
}

Öz

Anahtar Sözcükler

$\mathrm{Bu}$ araştırmada, özel yetenekli öğrencilerin mühendislik algılarının incelenmesi amaçlanmıştır. Araştırmada nitel araştırma yöntemi desenlerinden olgubilim kullanılmıştır. Araştırmanın çalışma grubunu, 2019-2020 Eğitim-Öğretim Yılı birinci döneminde Doğu Anadolu Bölgesi'nde yer alan bir bilim ve sanat merkezinde öğrenim gören 76 özel yetenekli öğrenci oluşturmaktadır. Veriler, çiz-yazanlat tekniği kullanılarak toplanmıştır. Verilerin analizinde içerik analizi yürütülmüştür. Öğrencilerin mühendislik kavramına yönelik çizimleri incelendiğinde, toplamda 253 çizim olmak üzere, 54 farklı çizim yaptıkları tespit edilmiştir. Mühendislik kavramına yönelik öğrenci çizimleri altı kategori altında toplanmış ve öğrencilerin en çok ürün kategorisi altında çizim yaptıkları belirlenmiştir. Bununla birlikte öğrencilerin daha çok inşaat, bilgisayar ve erkek bireylere yönelik çizim yaptıkları sonucuna ulaşılmıştır. Yapılan görüşmeler sonucunda da öğrencilerin önemli bir kısmı mühendisliğin otomotiv, bilgisayar ve inşaat alanları ile ilgili olduğunu belirtmişlerdir. Bu sonuca göre, özel yetenekli öğrencilerin toplum tarafından kabul görmüş mühendislik algılarını devam ettirdikleri ifade edilebilir. Bu kapsamda özel yetenekli öğrencilerin mühendislik algılarını zenginleştirmek için farklı mühendislik temelli STEM etkinliklerinin öğretim programlarında yer alması önerilmektedir.

STEM eğitimi

Mühendislik algisı

Özel yetenekli öğrenci

Çiz-yaz-anlat

Fenomenoloji

Makale Hakkında

Gönderim Tarihi

16 Aralık 2019

Kabul Tarihi

03 Temmuz 2020

Makale Türü

Araştırma Makalesi

DOI: 10.12984/egeefd.659348

\section{Examination of Engineering Perceptions of Gifted Students by Using Draw-Write-Tell}

\section{Abstract}

In this research, it was aimed to examine the engineering perceptions of gifted students. Phenomenology design, which is a qualitative research design, was used in the research. The sample group consisted of 76 gifted students studying in a Science and Art Center located in the Eastern Anatolia region in the 20192020 academic years. The multi-method method was used to collect the data, and the data were collected in accordance with the draw-write-tell technique. Content analysis was carried out in the analysis of the data. When the drawings of the students for engineering concept were examined, of 253 student drawings, there were 54 varying versions. Students' drawings related to the concept of engineering were grouped under six categories, and it was determined that the students mostly draw under the product category. In addition, it was concluded that students mostly draw on construction, computer, and male individuals. As a result of the interviews, a significant part of the students stated that engineering is related to automotive, computer, and construction fields. With this result, it can be stated that gifted students continue their engineering perceptions accepted by the society. In this context, it is suggested that different engineering-based STEM activities should be included in the curricula in order to enrich the engineering perceptions of gifted students.
Keywords

STEM education Engineering perception Gifted students

Draw-write-tell

Phenomenology

Article Info

Received

December 16, 2019

Accepted

July 03, 2020

Article Type

Research Paper

Atıf: Nacaroğlu, O. ve Arslan, M. (2020). Özel yetenekli öğrencilerin mühendislik algılarının çiz-yaz-anlat tekniği kullanılarak incelenmesi. Ege Eğitim Dergisi, 21(1), 112-128. doi:10.12984/egeefd.659348

\footnotetext{
* Sorumlu Yazar/Corresponding Author

1 (1) Milli Eğitim Bakanlığı, Malatya Bilim ve Sanat Merkezi, Türkiye, onacaroglu44@ gmail.com

2 (1) Milli Eğitim Bakanlığı, Malatya Bilim ve Sanat Merkezi, Türkiye, marslanmat@ gmail.com
} 


\section{Extended Abstract}

\section{Introduction}

Nowadays, engineering studies that have gained a different dimension under STEM (Science, Technology, Engineering, and Mathematics) education are based on applications that will enable students to learn meaningfully rather than solely learning theoretical knowledge (National Research Council [NRC], 2011a). In addition, it is aimed to bring engineering to the forefront by enabling students to turn to current problems in STEM education (Aydın, Saka, \& Guzey, 2018). With engineering studies, students are expected to become aware of current life problems, use scientific research steps like a scientist in the process of solving these problems, and demonstrate the ability to design (NRC, 2013). Therefore, the design component is the first and most important step in engineering-based STEM education (Aydın et al., 2018). Engineering design focused STEM activities provide students with problem solving and critical thinking skills, increases academic success and motivation, provides design opportunities, increases self-confidence and helps to discover special talented students (English \& King, 2015; Fan \& Yu, 2015). Because of the mentioned benefits, engineering and design skills have been added to the science curriculum (Milli Eğitim Bakanlığ $[\mathrm{MEB}], 2018$ ). The gradual spread of engineering design-oriented STEM training in schools brings up the revision of the school's structure and curriculum. It is thought that revealing the engineering perceptions of the students who have received this education will enable the future arrangements to be student-oriented. Therefore, it is important to examine the students' perceptions of engineering. In this context, the focus of the present study is on gifted students.

The underlying causes of the characteristics, perceptions, and behaviors of gifted students who care about science and research should be revealed (Çitil \& Ataman, 2018). Therefore, it is considered important to reveal the engineering perceptions of gifted students. However, various techniques should be used to determine students' perceptions of concepts (Dinç \& Üztemur, 2017). One of these techniques while explaining the concepts is a draw-write-tell technique that involves the process of drawing, writing and explaining the concept (Üztemur \& Dinç, 2018). From this point of view, the aim of the research is to examine engineering perceptions of gifted students in depth by using draw-write-tell technique. For this purpose, the following problems were sought;

- How are the drawings of gifted students about engineering?

- What are the views of gifted students about engineering?

\section{Method}

Phenomenology design, which is a qualitative research design, was used in the research. The sample group consisted of 76 gifted students studying in a Science and Art Center located in the Eastern Anatolia region in the 2019-2020 academic years. The multi-method method was used to collect the data, and the data were collected in accordance with the draw-write-tell technique. Content analysis was carried out in the analysis of the data.

\section{Findings}

When the drawings of the students for engineering concept were examined, it was found that of 253 student drawings, there were 54 varying versions (Table 2). When Table 2 was examined, it is seen that students mostly draw a construction site $(f=29)$ for the concept of engineering. However, computer $(f=26)$, male individual $(f=$ $16)$, machine $(f=12)$, airplane $(f=12)$, car $(f=11)$, experiment $(f=11)$ and robot $(f=10)$ codes were also very high. Student drawings for the concept of engineering were collected under categories such as product types, materials used, working areas, gender, and results. In the engineering types category, it is seen that most of the students' drawings were about construction $(f=8)$, computer $(f=7)$, and space $(f=6)$ engineering. This is followed by drawings for automotive $(f=5)$ and genetic engineering $(f=2)$. In addition, when the opinions of the participants about the characteristics of an engineer were examined, results were obtained that they should be hardworking, imaginative, intelligent, skilled, and researchful (Table 4).

\section{Discussion and Conclusion}

In this research, it was aimed to examine the engineering perceptions of gifted students studying at BILLSEM and participating in STEM trainings by using draw-write-tell technique. For this purpose, 76 special gifted students were studied. When the drawings of the students for engineering concept were examined, of 253 student drawings, there were 54 varying versions (Table 2). Therefore, it can be concluded that gifted students have different and rich perception levels in engineering. Ataman (2004), similar to findings of the current study, stated 
that gifted students have a rich perception levels on different subjects. However, it was concluded that student drawings mostly focused on construction, computer, and male individuals (Table 2). This result is similar to several studies in the literature (Bilen, Irkıçatal, \& Ergin, 2014; Cunnignham, Lachapelle, \& Lindgren-Streicher, 2005; Çakmak, Bilen, \& Taner, 2019; Fralick, Kearn, Thompson, \& Lyons, 2009; Gülhan \& Şahin, 2018; Silver \& Rushton, 2008). With this result, it can be concluded that gifted students maintain their perceptions of engineering accepted by society. It is important to evaluate this result from different perspectives. For example, Walker (2001) stated in his study that there was a perception that male individuals can do the engineering profession in male-dominated societies. Likewise, it is thought that students are more confronted with applications related to civil and computer engineering in daily life. In addition, it was found that the machine, plane and car drawings that students encountered in daily life were high (Table 2). Therefore, it can be concluded that learning environments should be created to differentiate students' perceptions of engineering. Since the developments in science and technology have led to the emergence of new engineering fields, it offers solutions to current problems, and gives importance to economic development, it is given more importance by the societies (NRC, 2013).

When the opinions of the participants about the characteristics of an engineer were examined, it was obtained that they should be hardworking, imaginative, intelligent, skilled and researchful (Table 4). According to this result, it can be interpreted that gifted students associate the characteristics of an engineer with their own characteristics. Because gifted students are interested in research, they want to learn fast and in-depth knowledge, they have advanced imagination, they put forward creative ideas, they are interested in science and mathematics, and they like to solve current problems by questioning (Akbaş \& Çetin, 2018; Schreglmann, 2016). As a result, it has been determined that although gifted students have different and rich perceptions about engineering, they have stereotypical thoughts in terms of the gender of the engineer and take into account the engineering fields accepted in their drawings for materials used in engineering. Despite this, it has been determined that gifted students have different perceptions about the working fields and types of engineering. In addition, gifted students associated the characteristics that an engineer should have with their own characteristics. Draw-write-tell technique was used to determine the engineering perceptions of gifted students. In this context, it can be interpreted that draw-write-tell technique is an applicable and alternative technique to examine students' perceptions of engineering.

It is suggested that science and mathematics teaching should be related to engineering fields for gifted students who are candidate engineers. In addition, it is important to choose activities in parallel with the rapid changes in science and technology, which include engineering themes.

Vocational career trainings can be organized with the participation of women engineers who have been successful in their field in order to change the existing perception of the gifted students towards the gender of the engineer and to see engineering as an option in their career choices. 


\section{Giriş}

Günümüzde tüm alanlarda hızlı değişimler yaşanmakta ve bu değişimler en çok sanayide kendini göstermektedir. Tarihsel süreç incelendiğinde, buhar sistemlerinin kullanılmaya başlanmasıyla birlikte birinci sanayi devrimi; petrolün ortaya çıkması ve üretimin artmasıyla birlikte ikinci sanayi devrimi; elektronik, bilgisayar ve internetin ortaya çıkmasıyla birlikte ise informatik devrim olarak ifade edilen üçüncü sanayi devrimi yaşanmıştır (Bulut ve Akçacı, 2017). Toplumların bilgi düzeylerinin artması sonucu ortaya çıkan ve hız, dijitalleşme, sistem yönünden diğer sanayi devrimlerinden farklılık gösteren son sanayi devrimi ise Endüstri 4.0 olarak ifade edilmektedir (Schwab, 2016). Özellikle insan gücü yerine makine gücünün önemsendiği bu sanayi devrimi sonucu yaşanan değişimler, bireylerin farklı becerilere sahip olmasını zorunlu kılmıştır. Bu zorunluluk da Eğitim 4.0 devriminin yaşanmasını ve yeni eğitim anlayışlarının ortaya çıkmasını sağlamıştır (Diwan, 2017). Bu eğitim anlayışlarından birisi de gerçek ve güncel dünya problemlerine disiplinler arası bir bakışla yaklaşmayı benimseyen ve bütüncül bir eğitimi önemseyen STEM eğitimidir (Benek ve Akçay, 2018).

Türkiye'de FETEMM olarak adlandırılan ve Fen (Science), Teknoloji (Technology), Mühendislik (Engineering) ve Matematik (Mathematics) kelimelerinin baş harflerinden oluşan STEM ve STEM eğitimine verilen değer, ekonomi ve teknolojide yaşanan hızlı değişimlerden dolayı giderek artmaktadır (Yıldırım ve Selvi, 2018). Ayrıca mevcut STEM eğitimi, STEM becerilerinin çağdaş, teknolojik, bilgiye dayalı, rekabetçi küresel ekonomide yenilik ve gelişim için çok önemli olduğu inancına dayanmakta (Hobbs, Cripps Clark ve Plant, 2017) ve birçok toplumun refahının STEM eğitimine bağlı olduğu ifade edilmektedir (Chubb, 2013). Bu kapsamda STEM eğitiminin doğru bir şekilde öğrenme ortamlarına yansıtılması önem arz etmektedir (Campbell, Speldewinde, Howitt ve MacDonald, 2018). Bununla birlikte bireylerin gelecekteki başarıları için gerekli görülen STEM eğitimini (Stohlmann, Moore ve Roehrig, 2012) doğru bir şekilde uygulamak ve öğrencilerin STEM alt boyutlarına yönelik yetkinliklerini geliştirmek, sürdürülebilir iş gücü açısından gerekli görülmektedir (Vasquez, Sneider ve Comer, 2013). STEM eğitimine verilen bu önem, STEM mesleklerinin ortaya çıkmasını sağlamıştır (Miaoulis, 2009). STEM meslekleri içerisinde de mühendisliğe, güncel problemlere çözüm sunduğu ve ekonomik kalkınmaya önem verdiği için toplumlar tarafından daha çok önem verilmektedir (National Research Council [NRC], 2013).

Günümüzde STEM eğitimi adı altında farklı bir boyut kazanan mühendislik uygulamaları, öğrencilere teorik bilgiden ziyade anlamlı öğrenmelerini sağlayacak uygulamalar üzerine kurgulanmıştır (NRC, 2011a). Ayrıca STEM eğitiminde öğrencilerin güncel problemlerin çözümüne yönelmesini sağlayarak mühendisliği ön plana çıkarmak amaçlanmaktadır (Aydın, Saka ve Guzey, 2018). Mühendislik uygulamaları ile öğrencilerden güncel yaşam problemlerinin farkına varmaları, bu problemi çözme sürecinde bir bilim insanı gibi bilimsel araştırma basamaklarını kullanmaları ve tasarım yapabilme becerisi göstermeleri beklenmektedir (NRC, 2013). Dolayısıyla mühendislik temelli STEM eğitiminde tasarım bileşeni ilk ve en önemli basamaktır (Aydın, Saka ve Guzey, 2018). Mühendislik tasarım odaklı STEM etkinliklerinin; öğrencilere problem çözme ve eleştirel düşünme becerisi kazandırdığı, akademik başarıyı ve motivasyonu arttırdığı, tasarım yapma imkânı sağladığı, özgüveni arttırdığı ve özel yetenekli öğrencilerin keşfedilmesine yardımcı olduğu ifade edilmektedir (English ve King, 2015; Fan ve Yu, 2015). Belirtilen faydalarından dolayı fen bilimleri öğretim programına mühendislik ve tasarım becerileri eklenmiştir (Milli Eğitim Bakanlı̆̆ı [MEB], 2018). Bununla birlikte mühendislik tasarım odaklı STEM eğitimlerinin okullarda giderek yaygınlaşması, okulun yapısı ile öğretim programlarının tekrar gözden geçirilmesini ve öğretmenlere yönelik hizmet içi eğitimlerin düzenlenmesini gündeme getirmektedir. Bu nedenle öncelikle bu eğitimi almış olan öğrencilerin mühendislik algılarını ortaya koymak, gelecekte yapılacak olan düzenlemelerin öğrenci odaklı olmasını sağlayacaktır. Dolayısıyla öğrencilerin mühendislik algılarının incelenmesi önem arz etmektedir. Bu kapsamda mevcut çalışmanın odak noktasını özel yetenekli öğrenciler oluşturmaktadır.

Özel yetenekli öğrenciler, yaşıtlarından en az bir özellik bakımından üst düzey performans gösteren bireylerdir (Çetinkaya ve İnci, 2019). MEB (2017) özel yetenekli öğrencileri, bir ya da daha fazla yetenek veya zekâ alanında akranlarına göre üst düzey performans gösteren, gizil güce sahip olan, diğer alanlarda ise ortalama performans gösteren çocuklar olarak tanımlamaktadır. Bu öğrencilerin yakın gelecekte toplumların en önemli karar verme mekanizmalarında yer alma potansiyeli en yüksek öğrenci grubu olduğu ifade edilmektedir (Akbaş ve Çetin, 2018). Özel yetenekli öğrenciler araştırmaya yoğun ilgi ve merak duyarlar; hızlı öğrenip derinlemesine bilgi edinmek isterler; gelişmiş hayal gücüne sahip olup yaratıcı fikirler öne sürerler; fen bilimlerine, matematiğe ve bilime karşı ilgi duyarlar ve güncel problemleri sorgulayarak çözmeyi severler (Schreglmann, 2016). Bilime merak duyup araştırmayı seven özel yetenekli öğrencileri topluma faydalı hâle getirmek için bu öğrencilerin özelliklerinin, algılayış biçimlerinin ve davranışlarının altında yatan nedenlerin ortaya çıkarılması gerekmektedir (Çitil ve Ataman, 2018). Dolayısıyla özel yetenekli öğrencilerin mühendislik algılarının ortaya konması önemlidir. Bununla birlikte öğrencilerin kavramlara yönelik algılarını belirlemek için çeşitli tekniklerin kullanılması gerekmektedir (Dinç ve Üztemur, 2017). Bu tekniklerden birisi de kavramları anlatırken öğrencilerin çizim yapma, yazma ve bu kavramı anlatma süreçlerini içeren çiz-yaz-anlat tekniğidir (Üztemur ve 
Dinç, 2018). Çiz-yaz-anlat tekniği, öğrencilerin belli kavramlar ekseninde önce çizim yapmaları, sonra bu kavrama yönelik düşüncelerini yazmaları, son olarak da kavramlar hakkında düşüncelerini ifade etmeleri temeline dayanır. Alanyazında çiz-yaz-anlat tekniğinin kullanıldığı belli sayıda çalışmalar olduğu tespit edilmiştir (Brownlee, Curtis, Spooner-Lane ve Feucht, 2017; Egan, Maguire ve Rooney, 2015; Üztemur ve Dinç, 2018). Örneğin çiz-yaz-anlat tekniğini kullanarak öğrencilerin epistemolojik inançlarını inceleyen Brownlee ve diğerleri (2017), tekniğin özellikle küçük yaştaki öğrencilerin epistemolojik inançlarını belirlemede etkili olduğunu belirtmişlerdir. Aynı şekilde Üztemur ve Dinç (2018) de öğrencilerin epistemolojik inançlarını incelerken çiz-yaz-anlat tekniğini kullanmışlar ve yeni bir yaklaşım olan bu tekniğin, ortaokul öğrencilerinin epistemolojik inançlarını belirlemede kullanışlı olduğu sonucuna ulaşmışlardır. Bu tekniğin özel yetenekli öğrencilerin mühendislik algılarını derinlemesine ortaya koymak adına etkili olabileceği düşünülmektedir.

Alanyazında farklı kesimdeki bireylerin STEM disiplinlerine ve STEM eğitimine yönelik algılarını inceleyen çalışmalar bulunmaktadır (Akaygün ve Aslan-Tutak, 2016; Balçın ve Ergün, 2019; Benek ve Akçay, 2018; Çakmak, Bilen ve Taner, 2019; Fralick, Kearn, Thompson ve Lyons, 2009; Gülhan ve Şahin, 2018; Karatas, Micklos ve Bodner, 2011; Timur ve İnançl1, 2018). Örneğin çizim formu kullanarak ortaokul öğrencilerinin havacılık ve uzay mühendisi algılarını araştıran Balçın ve Ergün (2019), öğrencilerin uzay ve havacılık mühendisinin yaptığı işlere yönelik yanlış kavramalarının bulunduğu sonucuna ulaşmışlardır. Veri toplama aracı olarak ölçek kullanan ve ortaokul öğrencilerinin mühendislik ve teknoloji algılarını araştıran Ergün (2018), öğrencilerin mühendislik algılarının yeterli olmadığı sonucuna ulaşmıştır. Ortaokul öğrencilerinin mühendis ve bilim insanı algılarını yapılan çizimler aracılığıyla inceleyen Gülhan ve Şahin (2018), öğrencilerin mühendisleri erkek olarak algıladıkları sonucuna ulaşmışlardır. Benzer şekilde özel yetenekli ortaokul öğrencilerinin mühendislik algılarını araştıran Koyunlu Ünlü ve Dökme (2017) de özel yetenekli öğrencilerin mühendisliğin tasarım boyutuna değindiklerini ve mühendisliği erkek mesleği olarak algıladıklarını belirtmişlerdir. Görüldüğü üzere, özel yetenekli öğrencilerin mühendislik algılarını çizimler veya ölçekler aracılığıyla inceleyen çalışmalar bulunsa da çiz-yaz-anlat tekniğinin kullanıldığı bir çalışmaya rastlanmamıştır. Fen bilimlerine, matematiğe ve bilime karşı ilgi duyan ve güncel problemleri sorgulayarak çözmeyi seven özel yetenekli öğrencilerin giderek önem kazanan mühendislik kavramına yönelik algılarının çiz-yaz-anlat tekniği kullanılarak incelenmesinin, alanyazına katkı sağlayacağı düşünülmektedir. Ayrıca elde edilen bulguların, mühendis tasarım odaklı STEM etkinlikleri planlayan öğretmenlere, özel yetenekli öğrencilerin öğretim programını hazırlayan uzmanlara ve bu alanda çalışma yapmak isteyen araştırmacılara önemli bir katkı sağlayacağı düşünülmektedir. Buradan hareketle çalışmanın amacı, özel yetenekli öğrencilerin mühendislik algılarını çiz-yaz-anlat tekniği kullanarak derinlemesine incelemektir. $\mathrm{Bu}$ amaç doğrultusunda aşağıda ifade edilen problemlere cevap aranmıştır:

- Özel yetenekli öğrencilerin mühendislik kavramına yönelik çizimleri nasıldır?

- Özel yetenekli öğrencilerin mühendislik kavramına yönelik görüşleri nasıldır?

\section{Yöntem}

\section{Araştırmanın Deseni}

$\mathrm{Bu}$ araştırmada, nitel araştırma yöntemi desenlerinden fenomenoloji deseni kullanılmıştır. Fenomenoloji, farkında olduğumuz fakat tam anlamıyla fikir sahibi olmadığımız olgu ve olayları bireylerin deneyimlerine göre derinlemesine inceleme imkânı veren bir desendir (Christensen, Johnson ve Turner, 2015). Dolayısıyla özel yetenekli öğrencilerin mühendislik algılarını çiz-yaz-anlat tekniği kullanılarak derinlemesine incelemeyi amaçlayan bu araştırmada en uygun desen olarak fenomenoloji deseni tercih edilmiştir.

\section{Çalıșma Grubu}

Araştırmanın çalışma grubunu, 2019-2020 Eğitim-Öğretim Yılı birinci döneminde Doğu Anadolu Bölgesi'nde yer alan bir bilim ve sanat merkezinde (BİLSEM) öğrenim gören 76 özel yetenekli öğrenci oluşturmaktadır. Araştırmanın çalışma grubunun belirlenmesinde amaçlı örnekleme yöntemlerinden ölçüt örnekleme yöntemi tercih edilmiştir (Yıldırım ve Şimşek, 2013). Bu kapsamda BİLSEM'de farklı öğretim programlarında öğrenim gören ve STEM eğitimi almış öğrenciler ile çalışma yürütülmüştür. Çalışma grubunda yer alan öğrencilere ait demografik bilgiler Tablo 1'de verilmiştir.

Tablo 1 incelendiğinde, araştırmaya 35 kadın (\% 46.05), 41 erkek (\% 53.95) özel yetenekli öğrencinin katıldı̆̆ görülmektedir. Bu katılımcıların 17'si destek eğitiminde, 15'i Bireysel Yetenekleri Fark Ettirme (BYF), 26's1 Özel Yetenekleri Geliştirme (ÖYG) ve 18'i Proje Üretimi ve Yönetimi programında öğrenimlerine devam etmektedir. 
Tablo 1

Katılımcılara Ait Demografik Bilgiler

\begin{tabular}{lcc}
\hline Demografik Özellikler & $f$ & $\%$ \\
\hline Cinsiyet & & 46.05 \\
Kadin & 35 & 53.95 \\
Erkek & 41 & \\
Yaş & & 36.85 \\
6-10 yaş & 28 & 47.37 \\
11-15 yaş & 36 & 15.78 \\
16-20 yaş & 12 & \\
BİLSEM grubu & & 22.36 \\
Destek & 17 & 19.74 \\
BYF (Bireysel Yetenekleri Fark Ettirme) & 15 & 34.22 \\
ÖYG (Özel Yetenekleri Geliştirme) & 26 & 23.68 \\
Proje Üretimi ve Yönetimi & 18 & \\
\hline
\end{tabular}

\section{Veri Toplama Aracı}

$\mathrm{Bu}$ araştırmada veri toplanması sürecinde birden fazla veri toplama yöntemi kullanılmıştır. Bu kapsamda veri toplamasında çiz-yaz-anlat tekniği kullanılmış ve araştırmacılar tarafından çiz-yaz-anlat formu geliştirilmiştir. Geliştirilen form, kapsam geçerliliğini sağlamak için eğitim bilimleri alanında çalışmalar yapan dört uzmanın görüşlerine sunulmuştur. Uzman görüşleri neticesinde öğrencilerden iki çizim yerine dört çizim yapabilecekleri şekilde form tekrar düzenlenmiştir. Ayrıca uzman görüşleri neticesinde demografik bilgiler kısmına, "İlgi duyduğunuz alan nedir?" ve "Seçmek istediğiniz meslek nedir?" soruları da eklenmiş ve öğrenciler tarafindan yazılacak kompozisyonda hangi konular üzerinde durulması gerektiği forma eklenmiştir. Bununla birlikte taslak form, anlaşılabilirlik ve yazım kuralları açısından bir Türkçe öğretmeninin görüşüne sunulmuştur. Geliştirilen form, BİLSEM'de farklı öğretim programlarında öğrenimlerine devam eden ikişer öğrenciye pilot çalışma kapsamında uygulanmış ve uygulama süresinin 30 dakika olmasına karar verilmiştir.

Veri toplama sürecinde üç aşama takip edilmiştir. Öncelikle öğrencilerden mühendislik kavramıyla ilgili dört farklı çizim yapmaları, daha sonra yapılan çizimlerden kendi düşüncelerine en yakın resmi dikkate alarak bir kompozisyon yazmaları istenmiştir. Örnek öğrenci çizimleri Şekil 1'de verilmiştir. Öğrencilerden kompozisyonlarında, belirledikleri resmi seçme nedenlerini, mühendislik kavramının kendilerinde neyi ifade ettiğini, bir mühendiste olması gereken özeliklerin neler olduğunu ve mühendislik uygulamalarının günlük yaşamdaki yerini anlatmaları istenmiştir. Üçüncü aşamada ise araştırmaya katılan tüm öğrencilerle odak grup görüşmeleri yapılmıştır. Odak grup görüşmeleri yaklaşık bir hafta sürmüştür. Görüşme sırasında ses kayıt cihazı kullanılmış ve katılımcılardan yazdıkları kompozisyonları okuyarak metinlerde mühendislik hakkında vurguladıkları noktaları ve bunun gerekçelerini açıklamaları beklenmiştir. Görüşmeler yaklaşık 20 dakika sürmüş ve görüşme yapılırken sessiz bir ortam tercih edilmiştir. Görüşme sonrası elde edilen ses kayıtları bir metne dönüştürülmüş ve içerik analizi yapılarak kodlar, kategoriler ve temalar belirlenmiştir.

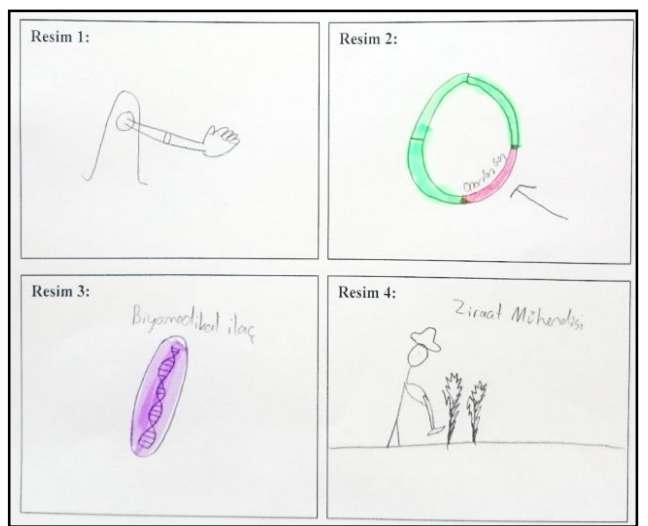

Şekil 1. Örnek Öğrenci Çizimleri

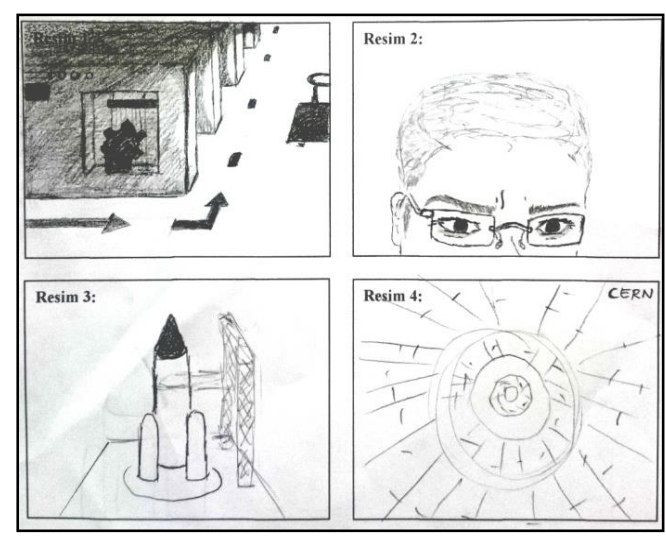




\section{Veri Analizi}

Verilerin analizinde tümevarımsal içerik analizi kullanılmıştır. Kaynağını veri setinden alan tümevarımsal içerik analizi yaklaşımında (Zhang ve Wildemuth, 2009) kodlar, katılımcıların ifadelerine göre belirlenir. Benzerlik gösteren kodlar bir arada değerlendirilir ve verilere ilişkin belgeler sistematik bir şekilde analize tabi tutulur (Yıldırım ve Şimşek, 2013). Dolayısıyla tümevarımsal içerik analizi, bireylerin sergilemiş oldukları davranışları ve onların doğasını anlamayı amaçlayan bir yaklaşımdır (Büyüköztürk, Kılıç-Çakmak, Akgün, Karadeniz ve Demirel, 2012). Bu kapsamda öncelikle her bir katılımc1 cevaplarına K1, K2, K3...K76 şeklinde numaralar verilmiş ve öğrenci çizimleri, kompozisyonlar ve odak grup görüşmeleri sonucu elde edilen veriler iki araştırmacı tarafından ayrı ayrı incelenmiş̧ir. İnceleme sonucu önemli kod ve boyutlar belirlenmiş ve belirlenen kodlara yönelik uygun kategori ve temalar oluşturulmuştur. Dolayısıyla küçük birimler genel bir çerçevede değerlendirilerek genel birimler şeklinde ifade edilmiştir (Tavşancıl ve Aslan, 2001). Ayrıca kodlamalar araştırma verilerine göre yapılmış ve verilerden çıkarılan kavramlara göre yapılan kodlama türü veri analizinde kullanılmıştır (Yıldırım ve Şimşek, 2013).

\section{Geçerlik Güvenirlik Önlemleri}

Nitel araştırmalarda geçerlik ve güvenirliğin sağlanabilmesi için inandırıcılık, aktarılabilirlik, teyit edilebilirlik ve tutarlık stratejileri kullanılmaktadır (Shenton, 2004). Bu kapsamda veri toplama aracı geliştirme sürecinde hazırlanan taslak form, uzman görüşüne sunulmuş ve bu görüşler neticesinde gerekli düzenlemeler yapılarak forma son şekli verilmiştir (inandırıcılık). Ayrıca katılımcı görüşleri bulgular kısmında doğrudan alıntı şeklinde verilmiştir. İnandırııılık kapsamında yapılan bu uygulamalar, çalışmanın iç geçerliğini arttırmaktadır (Lincoln ve Guba, 2013). Çalışmanın aktarılabilirliğini sağlamak adına, çalışmada amaçlı örnekleme yöntemi tercih edilmiş ve katılımcılara ait bilgiler, verilerin toplanması ve analizi detaylı bir şekilde açıklanmıştır. Aktarılabilirlik kapsamında yapılan bu uygulamalar, çalışmanın dış geçerliğini artırmaktadır (Lincoln ve Guba, 2013). Verilerin güvenirliğini sağlamak adına iç (tutarlılık) ve dış güvenirlik (teyit edilebilirlik) yöntemleri kullanılmıştır. Veri analizinde görev alan araştırmacıların görüşleri arasında tutarlılığı sağlamak için Miles ve Huberman (1994) tarafından geliştirilen güvenirlik formülü (Görüş Birliği / Görüş Birliği + Görüş Ayrıllığı) kullanılmıştır. Bu kapsamda her iki araştırmacının elde edilen verilere yönelik yaptığı değerlendirmeler 1şı̆ı̆ında kodlar, kategoriler ve temalar ile ilgili olarak görüş birliğine ya da ayrılı̆̆ına sahip oldukları noktalar belirlenmiştir. Görüşler arasındaki uyum oranı belirlenerek güvenirlik katsayısı hesaplanmıştır. Elde edilen güvenirlik katsayısı değeri .88 olarak bulunmuştur. Ayrıca uygulama sonrası her bir katılımcı ile iletişime geçilerek formda yer alan sorulara verdikleri cevaplar teyit edilmiştir.

\section{Etik Konular}

Tüm katılımcılara araştırma ile ilgili bilgilendirilmiş onam formu sunulmuş ve çalışmanın verileri gönüllü katılım ilkesi temel alınarak toplanmıştır. Çalışmada, Yükseköğretim Kurumları Bilimsel Araştırma ve Yayın Etiği Yönergesinde belirtilen tüm kurallara uyulmuştur.

\section{Bulgular}

\section{Öğrencilerin Mühendislik Kavramına Yönelik Çizimleri}

Araştırmanın birinci aşamasında "Özel yetenekli öğrencilerin mühendislik kavramına yönelik çizimleri nasıldır? ” sorusuna cevap aranmış olup öğrenci çizimlerine ait frekans değerleri Tablo 2' de verilmiştir:

Tablo 2

Ögrenci Çizimlerine Ait Frekans Değerleri

\begin{tabular}{lcllllll}
\hline Kodlar & $f$ & Kodlar & $f$ & Kodlar & $f$ & Kodlar & $f$ \\
\hline İşaat & 29 & Kadın birey & 6 & Bilim insanı & 2 & Hesap makinesi & 1 \\
Bilgisayar & 26 & Matematik & 6 & Genetik mühendisi & 2 & Lazer & 1 \\
Erkek birey & 16 & Uzay mühendisi & 6 & Iş1k & 2 & Maden mühendisi & 1 \\
Makine & 12 & Cetvel & 5 & Orman mühendisi & 2 & Makine mühendisi & 1 \\
Uçak & 12 & Kalem & 5 & Uçak mühendisi & 2 & Matematik mühendisi & 1 \\
Araba & 11 & Kodlama & 5 & Yoğun mesai & 2 & Meteoroloji & 1 \\
Deney & 11 & Otomotiv mühendisi & 5 & Zenginlik & 2 & Milimetrik kâğıt & 1 \\
Robot & 10 & Harita & 4 & Tren & 1 & Pergel & 1 \\
İşaat mühendisi & 8 & İş klyafeti & 4 & Ders çalışma & 1 & Silah & 1 \\
Uzay & 8 & Teknoloji & 4 & Elektrik & 1 & Toplantılar & 1 \\
Bilgisayar mühendisi & 7 & Tarım & 3 & Endüstri & 1 & Cern & 1 \\
Uzay aracı & 7 & Tasarım & 3 & Geometri & 1 & Zekâ & 1 \\
Genetik & 6 & Telefon & 3 & Gözlük & 1 & & \\
İş makinesi & 6 & Atom & 2 & Harita mühendisi & 1 & & \\
\hline
\end{tabular}


Tablo 2 incelendiğinde, mühendislik kavramına yönelik olarak öğrencilerin en çok inşaat $(f=29)$ çizdikleri görülmektedir. Bununla birlikte bilgisayar $(f=26)$, erkek birey $(f=16)$, makine $(f=12)$, uçak $(f=12)$, araba $(f=$ $11)$, deney $(f=11)$ ve robot $(f=10)$ kodlarına ait çizimlerin de fazla olduğu görülmektedir. Mühendislik kavramına yönelik öğrenci çizimleri; ürünler, türleri, kullanılan malzemeler, çalışma alanlarl, cinsiyetleri, sonuçları şeklinde temalar altında toplanmıştır. Öğrenci çizimlerine yönelik temalar ve kodları Tablo 3 'te verilmiştir:

Tablo 3

Cizimlere Yönelik Tema ve Kodlar

\begin{tabular}{|c|c|c|c|c|c|c|c|c|c|c|c|}
\hline Ürünler & & Türleri & & $\begin{array}{l}\text { Kullanılan } \\
\text { Malzemeler }\end{array}$ & & Çalışma Al & & Cinsiyetleri & & Sonuçları & \\
\hline Kodlar & $f$ & Kodlar & $f$ & Kodlar & $f$ & Kodlar & $f$ & Kodlar & $f$ & Kodlar & $f$ \\
\hline İnşaat & 29 & $\begin{array}{l}\text { İnşaat } \\
\text { mühendisi }\end{array}$ & 8 & Makine & 12 & Uzay & 8 & $\begin{array}{l}\text { Erkek } \\
\text { birey }\end{array}$ & 18 & $\begin{array}{l}\text { Yoğun } \\
\text { mesai }\end{array}$ & 2 \\
\hline Bilgisayar & 26 & $\begin{array}{l}\text { Bilgisayar } \\
\text { mühendisi }\end{array}$ & 7 & $\begin{array}{l}\text { İş } \\
\text { makinesi }\end{array}$ & 6 & Genetik & 6 & $\begin{array}{l}\text { Kadın } \\
\text { birey }\end{array}$ & 6 & Zenginlik & 2 \\
\hline Uçak & 12 & $\begin{array}{l}\text { Uzay } \\
\text { mühendisi }\end{array}$ & 6 & Cetvel & 5 & Matematik & 6 & & & $\begin{array}{l}\text { Ders } \\
\text { çalışma }\end{array}$ & 1 \\
\hline Araba & 11 & $\begin{array}{l}\text { Otomotiv } \\
\text { mühendisi }\end{array}$ & 5 & Kalem & 5 & Kodlama & 5 & & & Toplantılar & 1 \\
\hline Deney & 11 & $\begin{array}{l}\text { Genetik } \\
\text { mühendisi }\end{array}$ & 3 & Harita & 5 & Teknoloji & 4 & & & & \\
\hline Robot & 10 & $\begin{array}{l}\text { Orman } \\
\text { mühendisi }\end{array}$ & 3 & İş kıyafeti & 4 & Tarım & 3 & & & & \\
\hline Uzay aracı & 7 & $\begin{array}{l}\text { Uçak } \\
\text { mühendisi }\end{array}$ & 2 & $\begin{array}{l}\text { Hesap } \\
\text { makinesi }\end{array}$ & 1 & Atom & 2 & & & & \\
\hline Tasarım & 3 & $\begin{array}{l}\text { Harita } \\
\text { mühendisi }\end{array}$ & 2 & $\begin{array}{l}\text { Milimetrik } \\
\text { kağıt }\end{array}$ & 1 & Işık & 2 & & & & \\
\hline Telefon & 3 & $\begin{array}{l}\text { Maden } \\
\text { mühendisi }\end{array}$ & 2 & Pergel & 1 & Elektrik & 1 & & & & \\
\hline Gözlük & 1 & $\begin{array}{l}\text { Makine } \\
\text { mühendisi }\end{array}$ & 1 & & & Endüstri & 1 & & & & \\
\hline Lazer & 1 & $\begin{array}{l}\text { Meteoroloj } \\
\text { i }\end{array}$ & 1 & & & Geometri & 1 & & & & \\
\hline Silah & 1 & $\begin{array}{l}\text { Matematik } \\
\text { mühendisi }\end{array}$ & 1 & & & & & & & & \\
\hline Tren & 1 & & & & & & & & & & \\
\hline Toplam & 116 & Toplam & 41 & Toplam & 40 & Toplam & 39 & Toplam & 24 & Toplam & 6 \\
\hline
\end{tabular}

Tablo 3 incelendiğinde, öğrencilerin mühendislik türleri kategorisinde en çok inşaat $(f=8)$, bilgisayar $(f=7)$ ve uzay $(f=6)$ mühendisliğine yönelik çizim yaptıkları görülmektedir. Bunu otomotiv $(f=5)$ ve genetik mühendisliğine $(f=2)$ yönelik çizimler takip etmektedir. Bununla birlikte harita, maden, makine ve matematik mühendisliğine yönelik birer çizim yapmışlardır. Bu kategori altında yer alan örnek öğrenci çizimleri şu şekildedir:

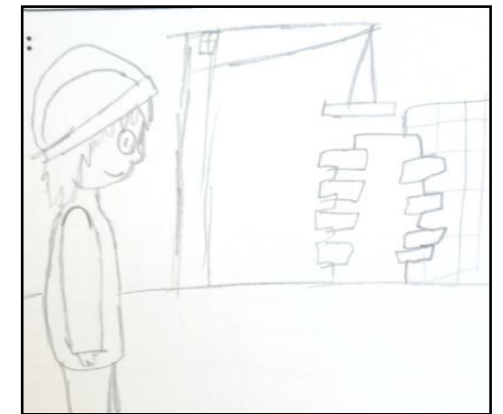

Şekil 2. K26’ye Ait Çizim

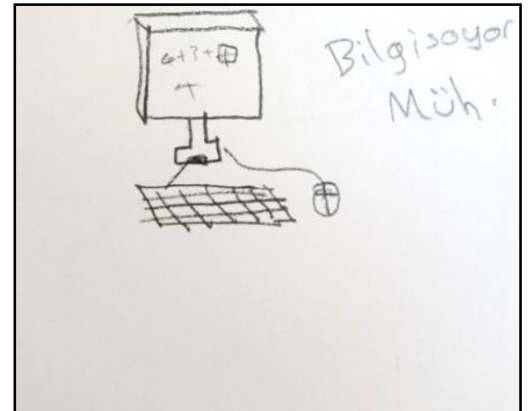

Şekil 3. K38'e Ait Çizim

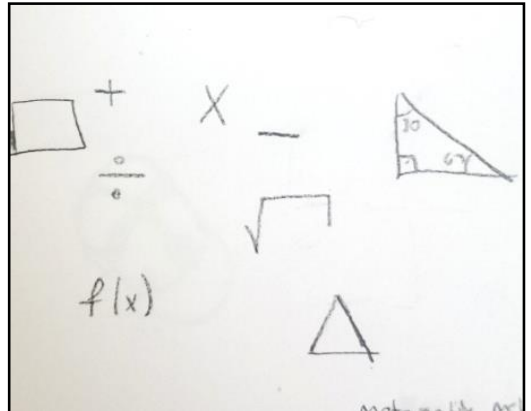

Şekil 4. K72'a Ait Çizim 
Ürünler kategorisine ait çizimlerde öğrencilerin, inşaat $(f=29)$, bilgisayar $(f=26)$, uçak $(f=12)$, araba $(f=11)$, deney $(f=11)$ ve robot $(f=10)$ çizimlerine yoğunlaştıkları görülmektedir. Bununla birlikte öğrencilerin uzay aracı ile ilgili yedi, tasarım ve telefon ile ilgili üçer çizim yaptıkları da tespit edilmiştir. Bu kategori altında yer alan örnek öğrenci çizimleri şu şekildedir:

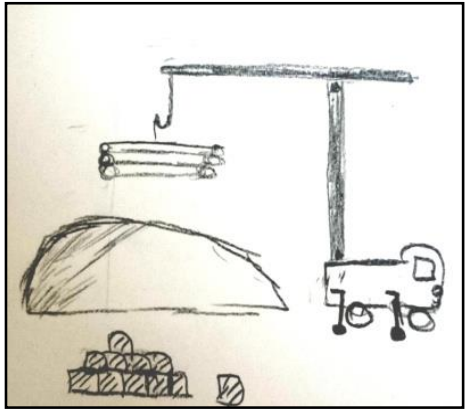

Sekil 5. K33'ye Ait Çizim

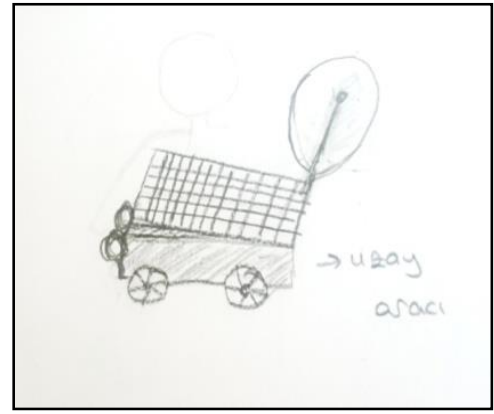

Sekil 6. K2'e Ait Çizim

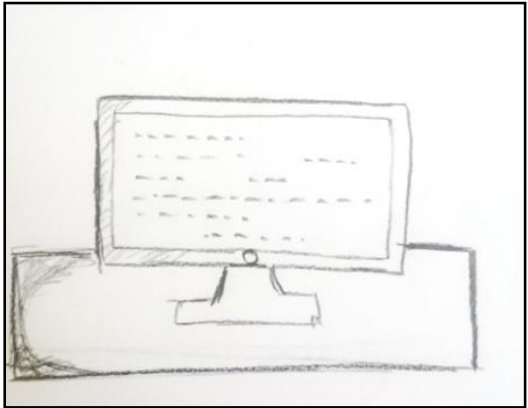

Sekil 7. K53’a Ait Çizim

Mühendislikte kullanılan malzemeler kategorisine ait çizimlerde öğrencilerin, makine $(f=12)$, iş makinesi $(f=$ $6)$, cetvel $(f=5)$ ve kalem $(f=5)$ çizimlerine yoğunlaştıkları görülmektedir. Bu kategori altında yer alan örnek öğrenci çizimleri şu şekildedir:

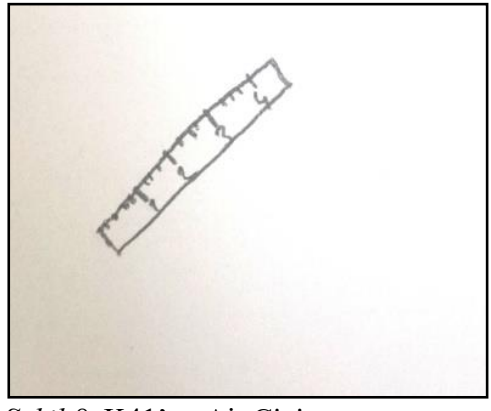

Şekil 8. K41'ye Ait Çizim

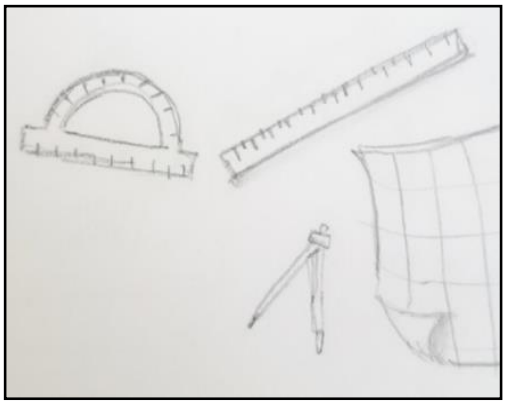

Sekil 9. K19'e Ait Çizim

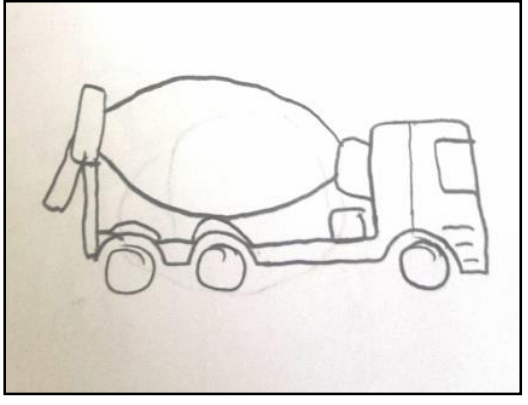

Sekil 10. K13'a Ait Çizim

Çalışma alanları kategorisine yönelik olarak öğrencilerin uzay $(f=8)$, genetik $(f=6)$, matematik $(f=6)$ ve kodlama $(f=5)$ çizimlerine yoğunlaştıkları görülmektedir. Bununla birlikte teknolojiyle ilgili dört, tarımla ilgili üç çizim de tespit edilmiştir. Bu kategori altında yer alan örnek öğrenci çizimleri şu şekildedir:

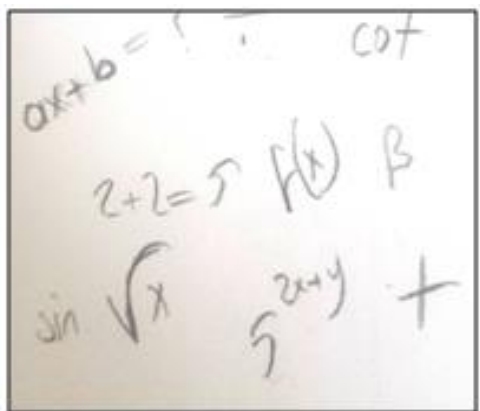

Şekil 11. K29’ye Ait Çizim

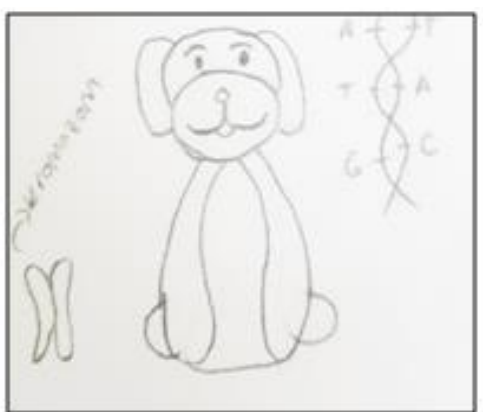

Şekil 12. K15'e Ait Çizim

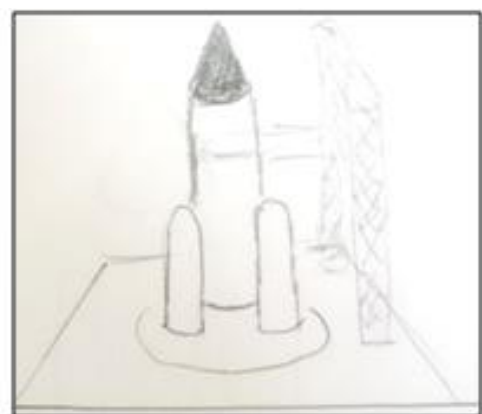

Şekil 13. K43’a Ait Çizim

Mühendislik alanında çalışmalar yapan kişilerin cinsiyetlerine vurgu yapan çizimler incelendiğinde, erkek bireylerin $(f=18)$ kadın bireylerden $(f=6)$ daha fazla çizildiği tespit edilmiştir. Bu bireyler genellikle gözlüklü, masa başında yoğun bir şekilde çalışan bireyler şeklindedir. Mühendislik alanında çalışmaların sonuçlarına vurgu yapan çizimler incelendiğinde, yoğun mesai ve zenginliğe ait iki, ders çalışma ve toplantılara ait bir çizim tespit edilmiştir. Bu kategori altında yer alan örnek öğrenci çizimleri şu şekildedir: 


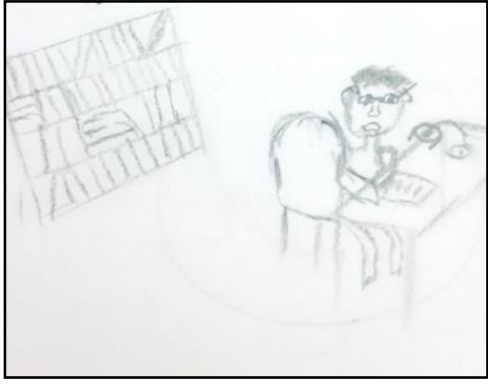

Şekil 14. K7'ye Ait Çizim

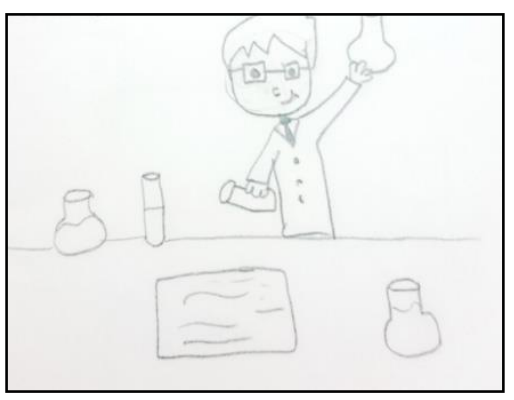

Şekil 15. K51'e Ait Çizim

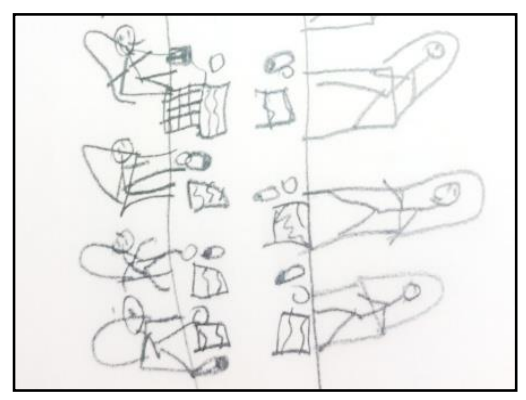

Şekil 16. K63'e Ait Çizim

\section{Özel Yetenekli Öğrencilerin Mühendisliğe Yönelik Yazılı İfadeleri ve Görüşleri}

Araştırma sonucu elde edilen yazılı ifadeler ve odak grup görüşmelerine ait bulgular birlikte verilmiş olup katılımcılardan yazdıkları kompozisyonları okuyarak metinlerde mühendislik hakkında neyi vurguladıklarını, resmi seçme nedenlerini, bir mühendiste olması gereken özellikleri ve mühendislik uygulamalarının günlük yaşamdaki yerini gerekçeleri ile birlikte açıklamaları istenmiştir. Elde edilen bulgular Tablo 4 'te verilmiştir:

Tablo 4

Yazılı Ifadeler ve Odak Grup Görüşmeleri

\begin{tabular}{|c|c|c|c|c|c|c|c|}
\hline \multirow{3}{*}{$\begin{array}{l}\text { Mesleği Yapan Kişilerin } \\
\text { Özellikleri } \\
\text { Kodlar }\end{array}$} & \multicolumn{5}{|c|}{ Mühendislik } & \multirow{2}{*}{\multicolumn{2}{|c|}{ Katkıları }} \\
\hline & & Günlük Yaşamdaki Yer & & İlgili Olduğu Alanlar & & & \\
\hline & $f$ & Kodlar & $f$ & Kodlar & $f$ & Kodlar & $f$ \\
\hline Çalışkan olmalı & 22 & Her alanda yer alır & 39 & Otomotiv & 41 & Hayatı kolaylaştırır & 45 \\
\hline $\begin{array}{l}\text { Hayal dünyası geniş } \\
\text { olmalı }\end{array}$ & 19 & $\begin{array}{l}\text { Şehir } \\
\text { düzenlemelerinde }\end{array}$ & 12 & Bilgisayar & 32 & Mutluluk verir & 34 \\
\hline $\begin{array}{l}\text { Zeki ve becerikli } \\
\text { olmalı }\end{array}$ & 16 & $\begin{array}{l}\text { Genetik hastalıkların } \\
\text { tedavisinde }\end{array}$ & 9 & İnşaat & 29 & $\begin{array}{l}\text { Ekonomik kazanç } \\
\text { sağlar }\end{array}$ & 32 \\
\hline $\begin{array}{l}\text { Araştırmacı olmalı } \\
\text { ve işini sevmeli }\end{array}$ & 10 & $\begin{array}{l}\text { Teknolojik } \\
\text { cihazların } \\
\text { üretiminde }\end{array}$ & 1 & Teknoloji & 18 & $\begin{array}{l}\text { Merak duygusunu } \\
\text { arttırır. }\end{array}$ & 16 \\
\hline İleri görüşlü olmalı & 9 & & & Mimarlık & 13 & Geleceğe 1şık tutar & 13 \\
\hline $\begin{array}{l}\text { Planlı ve disiplinli } \\
\text { olmalı }\end{array}$ & 7 & & & Yazılım & 12 & Bilimsel bilgi artar & 4 \\
\hline Sabırlı olmalı & 7 & & & Uzay çalışmaları & 9 & & \\
\hline Üretken olmalı & 7 & & & Elektrik & 7 & & \\
\hline Cesaretli olmalı & 5 & & & Eğitim & 6 & & \\
\hline Yaratıcı olmalı & 4 & & & Sağlık & 6 & & \\
\hline Yenilikçi olmalı & 3 & & & Fizik ve matematik & 4 & & \\
\hline $\begin{array}{l}\text { Tasarım kabiliyetleri } \\
\text { yüksek olmalı }\end{array}$ & 3 & & & & & & \\
\hline Dürüst olmalı & 2 & & & & & & \\
\hline $\begin{array}{l}\text { Estetiğe önem } \\
\text { vermeli }\end{array}$ & 2 & & & & & & \\
\hline
\end{tabular}

Tablo 4'teki bulgular incelendiğinde dikkat çeken en önemli nokta, özel yetenekli öğrencilerin büyük bir kısmının (\% 28.94) bir mühendisin çalışkan olması gerektiği konusunda hemfikir olmalarıdır. Örneğin K11 "Artık her alanda hızlı değişimler yaşanıyor ve bir mühendis dolayısıyla çalışkan olmall." şeklinde görüş bildirirken K45 "Bence bir mühendis her şeyden önce çallşkan olmall." demiştir. Bununla birlikte katılımcıların \% 25'inin, bir mühendisin hayal dünyasının geniş olması gerektiğini düşündükleri görülür. Bu konuda K37 “İyi bir mühendiste olması gereken en önemli özellik geniş bir hayal dünyası olmalıdır. Çünkü her şey hayal etmekle başlar." derken K12 “Bir mühendis hayal kurmall. Yoksa sadece olduğu yerde kalır." şeklinde görüş bildirmiştir. Dikkate değer bir diğer nokta ise katılımcıların \% 21.05'inin bir mühendisin zeki ve becerikli olması gerektiğine vurgu yaptıklarıdır. Bu kapsamda K19 "Zekâ ve kabiliyet olmadan mühendislik yapılamaz." şeklinde görüş belirtirken K65 düşüncesini, "Bir mühendis bence özellikle sayısal zekâsı iyi olmalıdır." şeklinde ifade etmiştir.

Katılımcıların \% 13.15'i, bir mühendisin işini sevmesi ve araştırmacı olması gerektiğini düşünürken, \% 11.84 'ü bir mühendisin ileri görüşlü olması gerektiğini vurgulamıştır. Bununla birlikte yedişer katılımcı bir mühendisin planlı, sabırlı ve üretken olması gerektiğini ifade etmiştir. Bir mühendisin sahip olması gereken diğer özelliklere yönelik çeşitli öğrenci görüşleri aşağıda şöyledir: 
Mühendislik keskin bakışlar ve zekâ gerektirir. [K15]

Bence bir mühendiste olması gereken en önemli ve gerekli özellik yenilikçi olmaktır. [K59]

Estetik olmadan mühendislik olmaz. Bunun için mühendis estetik duyguya sahip olmall. [K26]

Bir mühendis dürüst olmalı, yoksa bilgisini yanlış amaçlı kullanabilir. [K33]

Bir mühendis bildiğim kadarıyla çok çalışmalı. Bunun içinde sabırlı olması gerekir. [K32]

Mühendis, hayatımızı kolaylaştırır ve değişen dünyada geleceğimize yön verir. [K71]

Araştırmaya katılan özel yetenekli öğrencilerin yarısından fazlası (\% 51.31) mühendislik uygulamalarının günlük yaşamın her alanında yer aldığını belirtmișlerdir. Bu konuda K41 "Mühendislik her alanda ihtiyacımızı karşllayan bir meslek grubudur." derken K35 "Mühendislik uygulamalarl günlük hayatta neredeyse her yerde kullanilıyor. Şehir düzenlemelerinden uzayın derinliklerini araştırmaya ve genetiğe kadar her alanda araştırmayı sağlıyor.” şeklinde görüş belirtmiştir. Katılımcıların önemli bir kısmı da (\% 15.78) mühendisliğin özellikle inşaat ve şehir düzenlemelerinde önemli olduğu görüşünü paylaşır. Örneğin K51 bu konudaki görüşünü "Aslında mühendislik derken hemen hemen herkese göre inşaat ve şehir düzenlemesi anlaşılmaktadır. Bu bakımdan en önemli yeri inşaat sektöründe yer bulmuştur." şeklinde ifade ederken K49 "Mühendislik derken binaların yapımı, şekli, şehir planlaması aklıma geliyor...” ş̧eklinde belirtmiştir. Diğer katılımcılardan farklı olarak dokuz katılımcı, mühendisliğin genetik hastalıkların tedavisinde taşıdığı öneme vurgu yapmışlardır. Söz gelimi K76 "Mühendislik sayesinde hastalıklardan kurtulabiliniyor. Mühendislik ilerledikçe birçok genetik hastalıklar iyileştirilebilir." derken K68 bu konudaki düşüncesini "Mühendislik uygulamaları ile insan genom haritası çıkarılmıştır. Dolayısıyla mühendislik genetikte kendine büyük bir yer bulmuştur.” şeklinde ifade etmiştir.

Katılımcıların yine yarısından fazlası (\% 53.94) mühendisliğin otomotiv sektörü ile yakından ilgili olduğunu düşünür. Bu kapsamda görüş belirten K3 "Günümüzde mühendislik en çok otomobil sektörü ile yakından ilişkilidir.” derken K11 “Otomotiv sektörü mühendislik sayesinde bu noktaya gelmiştir. Daha da ilerleyeceğini düşünüyorum." şeklinde görüș belirtmiștir. Katılımcıların büyük bir kısmı (\% 42.10) mühendisliğin bilgisayar teknolojileri ile yakından ilgili olduğunun altını çizer. Bu konuda K14 "İleride bilgisayar mühendisi olmak istiyorum. Çünkü mühendisliği seviyorum ve mühendisliğin bilgisayarla ilgili olduğunu düşünüyorum.” şeklinde görüş̧ belirtirken K24 "Çizimlerimden de anlaşılacağl gibi mühendislik bilgisayarla ilgilidir. Her yerde bilgisayar kullanmak zorundayız. Bu gelişmelerin sebebi mühendisliktir.” der. Yine katılımcıların önemli bir kısmı (\% 38.15) mühendisliğin inşaat sektörü ile ilgili olduğunu belirtmişlerdir. Bu bulgular çerçevesinde katılımcıların büyük bir çoğunluğunun mühendisliğin daha çok otomotiv, bilgisayar ve inşaat alanları ile ilgili olduğu hususunda görüş belirttikleri görülmektedir.

Araştırmaya katılan 18 katılımcı mühendisliğin teknolojiyle; 13 katılımcı mimarlıkla; 12 katılımcı yazılımla; 9 katılımcı ise uzay çalışmalarıyla ilgisi bulunduğunu ifade etmişlerdir. Mühendisliğin ilişkilendirildiği alanlara yönelik olarak öğrenci görüşlerinden bazıları şöyledir:

Uzay çalışmaları artık önemli bir hale geldi. Bunun sebebi mühendisliğin gelişmesidir. [K8]

Bana göre artık yazılım olmadan hiçbir şey olmaz. Dolayısıyla mühendisliğin ilgili olduğu alan olarak yazılımı görüyorum. [K33]

Teknolojinin şimdiki hale gelmesinin en önemli sebebi mühendisliktir. [K17]

Uzay bana göre inanılmaz bir yerdir. Bu şekilde düşünmemin sebebi mühendislerin bu alana yönelmesidir. [K73]

Günlük yaşamımızı mühendisliğin mucizelerine borçluyuz. Bu mucizenin kahramanları da matematik ve fiziktir. [K70]

Insan yaşamı giderek daha önemli hale geldi. Değişen birçok şey insan sağllğını tehdit ediyor. Bu durumun çözülmesinde mühendislik gereklidir. [K63]

Ĕ̆itim olmadan hiçbir şey olmaz. Günümüzde eğitim teknolojilerinin gelişmesinde mühendislik çok önemlidir. [K49]

Elektrik olmazsa hiçbir şey çalışmaz. Bunun için mühendislik öncelikle elektrik ile ilgilidir. [K11].

Mühendisliğin günlük hayata katkılarına dair öğrenci görüşleri incelendiğinde, öğrencilerin önemli bir kısmının (\% 59.21) mühendislik uygulamalarının hayatı kolaylaştırdığını ifade ettikleri görülür. Bu konuda K51 "Mühendislik uygulamaları günümüzde binalardan ulaşıma, arabalardan telefona kadar karşımıza çıkmaktadır ve bunlar hayatımızı kolaylaştırmaktadır." şeklinde görüş belirtirken, K45 düşüncesini “Yaşadı ğımız çağda mühendisliğin sayesinde hayatımız kolaylaşıyor." biçiminde ifade etmiştir. Mühendislik uygulamalarının 
mutluluk verdiğini belirten katılımcıların oranı \% 44.73'tür. Örneğin K9 bu konuda “Katıldı̆̆ım ĕgitimde mühendislik çalışmaları yaptık ve bir şeyler ürettikçe mutlu olduğumun farkına vardım.” derken K21 “Mühendis yaptığ l projeyi sonuçlandırırsa mutlu olur.” şeklinde görüş belirtmiştir. Katılımcıların bir kısmı ise (\% 42.10) mühendisliğin bireysel ve toplumsal ekonomik kazanç getirdiğine inanmaktadır. Bu görüşlerden farklı olarak 16 katılımcı mühendisliğin merak duygusunu arttırdığını; 13 katılımcı geleceğe 1şık tuttuğunu; 4 katılımc1 ise bilimsel bilginin artmasını sağladığını belirtmişlerdir. Mühendisliğin sağladığı diğer katkılara yönelik olarak çeşitli öğrenci görüşleri şöyledir:

Mühendislik geliştikçe yeni icatlar, yeni bilgiler elde edilecektir. [K50]

Mühendis olan kişinin merak duygusunun arttı̆̆ını düşünüyorum. Çünkü problemleri görüp çözüm üretmesi için merakll olmasl gerekiyor. [K59]

Mühendislikle uğraşan kişiler kendilerini geliştirirlerse ekonomik olarak gelişebilirler. [K8]

\section{Sonuç ve Tartışma}

Bu araştırmada, BİLSEM'de öğrenim gören ve STEM eğitimlerine katılmış olan özel yetenekli öğrencilerin mühendisliğe yönelik algılarının çiz-yaz-anlat tekniği kullanılarak incelenmesi amaçlanmıştır. Bu amaç doğrultusunda 76 özel yetenekli öğrenci ile çalışma yürütülmüştür. Öğrencilerin mühendislik kavramına yönelik çizimleri incelendiğinde, toplamda 253 çizim olmak üzere 54 farklı çizim yaptıkları tespit edilmiştir (Tablo 2). Bu durum, özel yetenekli ögrencilerin mühendislik konusunda farklı ve zengin algı düzeylerine sahip oldukları şeklinde yorumlanabilir. Ataman (2004), bu sonucu destekler nitelikte, özel yetenekli öğrencilerin farklı konularda zengin algı düzeylerine sahip olabileceklerini belirtmiştir. Bununla birlikte öğrencilerin çizimlerinde en çok inşaat, bilgisayar, uçak, makine ve erkek bireylere yoğunlaştıkları sonucuna ulaşılmıştır (Tablo 2). Elde edilen bu sonuç bazı çalışmalarla benzerlik göstermektedir (Balçın ve Ergün, 2019; Bilen, Irkıçatal ve Ergin, 2014; Cunnignham, Lachapelle ve Lindgren-Streicher, 2005; Çakmak ve diğ., 2019; Ergün, 2018; Fralick ve diğ., 2009; Gülhan ve Şahin, 2018; Koyunlu Ünlü ve Dökme, 2017; Silver ve Rushton, 2008). Örneğin ortaokul öğrencilerinin mühendislik algılarını inceleyen Bilen, Irkıçatal ve Ergin (2014), öğrencilerin en çok inşaat ve bilgisayar mühendisi çizdikleri sonucuna ulaşmışlar ve STEM eğitiminin gerekliliğini ortaya koymuşlardır. Aynı şekilde Ergun ve Balcin (2019), öğrencilerin, mühendislerin yaptıkları işleri, inşaat işçileri ya da tamircilerin yaptıkları işlerle karıştırdıkları sonucuna ulaşmışlardır. Bu araştırmada ayrıca özel yetenekli öğrencilerin önemli bir kısmının erkek mühendis bireyler çizdikleri belirlenmiş olup bu sonuç başka bazı çalışmalarla da benzerlik göstermektedir (Balçın ve Ergün, 2019; Çetin ve Asiltürk, 2017; Ergun ve Balcin, 2019; Gülhan ve Şahin, 2018; Knight ve Cunningham, 2004; Koyunlu Ünlü ve Dökme, 2017). Söz gelimi Gülhan ve Şahin (2018), öğrencilerin, mühendisleri erkek ve çoğunlukla yalnız çalışan bireyler olarak algıladıklarını belirtmişlerdir. Bu sonuca göre, özel yetenekli öğrencilerin toplum tarafından kabul görmüş mühendislik algılarını devam ettirdikleri yorumuna varılabilir. Elde edilen bu sonucun farklı açılardan değerlendirilmesi önemli görülmektedir. Çünkü mühendisliğin bir erkek mesleği olarak algılanması, öğrencilerin meslek seçimini de etkilemektedir (Koyunlu Ünlü ve Dökme, 2017). Ayrıca özel yetenekli öğrencilerin akranları gibi kabul görmüş mühendislik algılarına sahip olmaları, araştırılması gereken önemli bir konu olarak görülmektedir. Özel yetenekli öğrenciler ile akranlarının benzer mühendislik algısına sahip olmalarında birçok durum etkili olabilmektedir. Örneğin Walker (2001) yaptığı çalışmada, erkek egemen toplumlarda mühendislik mesleğini erkek bireylerin yapabileceğine yönelik algının olduğunu ifade etmiştir. Aynı şekilde öğrencilerin daha çok erkek bireylerin tercih ettiği inşaat ve bilgisayar mühendisliğine yönelik uygulamalar ile günlük hayatta daha fazla karşılaşmalarının da etkili olduğu düşünülmektedir. Buradan hareketle öğrencilerin mühendislik algılarını farklılaştıracak öğrenme ortamlarının oluşturulması gerektiği sonucuna varılabilir. Çünkü bilim ve teknolojideki gelişmeler yeni mühendislik alanlarının ortaya çıkmasını sağlamakta ve mühendisliğe, güncel problemlere çözüm sunduğu ve ekonomik kalkınmaya önem verdiği için toplumlar tarafından daha çok önem verilmektedir (NRC, 2013). Bu kapsamda Balçın ve Ergün (2019) farklı mühendislik alanlarının öğrencilere tanıtılması ve bu alanlara yönelik uygulamaların eğitim ortamlarında yer almasının önemli olduğunu belirtmişlerdir. Benzer şekilde Koyunlu Ünlü ve Dökme (2017) özel yetenekli öğrencilerin mühendisliğe ilişkin algılarını geliştirmek için öğrenme ortamları düzenlenmesi gerektiğini belirtmişlerdir. Ayrıca Balçın ve Topaloğlu (2019) mühendis algıları yetersiz olan kız öğrenciler için gerekli çalışmaların yapılmasını önermişlerdir.

Öğrenci çizimlerine içerik analizi yapıldığında ise öğrencilerin en çok mühendislik uygulamaları sonucu ortaya çıkan ürünlere yönelik çizim yaptıkları sonucuna ulaşılmıştır (Tablo 3). Bu çizimlerde de inşaat, bilgisayar, uçak ve araba çizimlerine yoğunlaştıkları görülmektedir. Elde edilen bu sonuç, öğrencilerle yürütülen odak grup görüşmeleri sonucu elde edilen bulguları desteklemektedir (Tablo 4). Bu görüşmelerde öğrencilerin önemli bir kısmı mühendisliğin otomotiv, bilgisayar ve inşaat alanları ile ilgili olduğunu belirtmişlerdir. Bu sonuçlara göre, özel yetenekli öğrencilerin mühendislik algılarını zenginleştirmek için farklı mühendislik temelli STEM etkinliklerinin öğretim programlarında yer alması gerektiği yorumu yapılabilir. Bu kapsamda fen bilimlerine, 
matematiğe ve mühendisliğe ilgi duyan (Schreglmann, 2016) özel yetenekli öğrencilerin eğitiminde farklılaştırılmış öğretim programlarının uygulanması önem arz etmektedir. Çünkü mühendislik tasarım odaklı program uygulanan öğrencilerin mühendislik algılarının değişeceği, fen bilimlerinde başarılarının ve tutumlarının artacağı vurgulanmaktadır (Wendell ve Rogers, 2013). Araştırmadan elde edilen bir diğer sonuç, öğrencilerin mühendislik uygulamalarında kullanılan malzemelere yönelik çizimlerinin oldukça fazla olduğudur (Tablo 3). Bu kategori altında öğrencilerin makine, iş makinesi, cetvel, kalem ve harita çizimlerine yoğunlaştıkları bu çizimlerin de inşaat, makine, bilgisayar, harita gibi kabul görmüş mühendislik alanlarına/aletlerine yönelik olduğu söylenebilir. Buradan hareketle öğrencilerin mühendislikte ortaya çıkan ürünlere ve bu ürünlerin oluşturulmasında kullanılan aletlere yönelik algılarının yüksek olduğu yorumu yapılabilir. Bu sonuç, benzer bazı çalışmaların sonuçlarıyla uyuşmaktadır (Balçın ve Ergün, 2019; Çetin ve Asiltürk, 2017; Ergün ve Balçin, 2019; Knight ve Cunningham, 2004).

Alanyazında amaca hizmet eden etkinlikler ile birlikte fen, teknoloji ve matematik alanlarının mühendislik alanına dâhil edilerek mühendislik eğitiminin gerçekleştirilebileceği ifade edilmektedir (NRC, 2011). Dolayısıyla öğrencilerin kabul görmüş mühendislik alanlarından farklı mühendislik alanlarına yönelmelerini sağlamak için, mühendislik eğitiminin farklı alanlarla entegresinin sağlanması gerektiği yorumu yapılabilir. Bu çalışmada öğrencilerin, mühendisliğin çalışma alanlarına yönelik olarak en çok uzay, genetik, matematik ve kodlama alanlarına yönelik çizimler yaptıkları sonucuna ulaşılmıştır (Tablo 3). Aynı şekilde mühendislik türleri kategorisinde inşaat ve bilgisayar mühendisliğinin yanı sıra uzay mühendisliğine yönelik çizim yaptıkları da tespit edilmiştir. Elde edilen bu bulguya göre özel yetenekli öğrencilerin mühendisliğin çalışma alanları ve türlerine ilişkin farklı algılara sahip oldukları yorumu yapılabilir. Bu sonuç Ergun ve Balcin (2019) tarafindan yapılan çalışmayla farklılık göstermektedir. Ergun ve Balcin (2019) çalışmalarında, özel öğrencilerin mühendisliğin çalışma alanlarından kimya, havacılık ve uzay, gıda, genetik gibi pek çok alanı bilmediklerini belirtmişlerdir. Mevcut çalışmada ise özel yetenekli öğrencilerin farklı alanlara yönelik çizim yapmalarında, katıldıkları STEM eğitimlerinin etkili olduğu düşünülmektedir. Çünkü STEM eğitimleri, öğrencilerin STEM mesleklerine yönelik algılarının ve görüşlerinin değişmesine sebep olabilmektedir (King ve English, 2016; Knezek, Christensen, Tyler-Wood ve Periathiruvadi, 2013). Bu sonuç, Lamb, Akmal ve Petrie (2015) tarafından yapılan ve üç yıl süren çalışmanın sonuçları ile benzerlik göstermektedir.

Katılımcıların bir mühendisin özelliklerine yönelik görüşleri incelendiğinde ise çalışkan, hayal dünyası geniş, zeki, becerikli ve araştırmacı olmaları gerektiğine yönelik sonuçlar elde edilmiştir (Tablo 4). Bu sonuca göre özel yetenekli öğrencilerin bir mühendiste olması gereken özellikleri kendi özellikleri ile bağdaştırdığı yorumu yapılabilir. Çünkü özel yetenekli öğrenciler araştırmaya yoğun ilgi ve merak duyarlar, hızlı öğrenip derinlemesine bilgi edinmek isterler, gelişmiş hayal gücüne sahip olup yaratıcı fikirler öne sürerler, fen bilimlerine, matematiğe ve bilime karşı ilgi duyarlar ve güncel problemleri sorgulayarak çözmeyi severler (Akbaş ve Çetin, 2018; Schreglmann, 2016). Bununla birlikte katılımcılar mühendislik uygulamalarının yaşamın her alanında, özellikle şehir düzenlemelerinde, genetik hastalıkların tedavisinde ve teknolojik cihazların üretiminde yer aldığını belirtmişlerdir (Tablo 4). Aynı şekilde mühendislik uygulamalarının hayatı kolaylaştırma, mutluluk verme, ekonomik kazanç edinme ve geleceğe 1şık tutma gibi katkıları olduğunu belirtmişlerdir. Bu sonuç çerçevesinde özel yetenekli öğrencilerin mühendislik uygulamalarının ilgili olduğu alanlara ve katkılarına yönelik farklı algılara sahip oldukları yorumu yapılabilir

Sonuç olarak özel yetenekli öğrencilerin mühendislik ile ilgili farklı ve zengin bir algıya sahip olmalarına rağmen, mühendisin cinsiyeti açısından basmakalıp düşünceye sahip oldukları ve mühendislikte kullanılan malzemelere yönelik çizimlerinde, kabul görmüş mühendislik alanlarını dikkate aldıkları tespit edilmiştir. Buna rağmen özel yetenekli öğrencilerin mühendisliğin çalışma alanları ve türlerine yönelik farklı algıya sahip oldukları belirlenmiştir. Ayrıca özel yetenekli öğrencilerin, bir mühendiste olması gereken özellikleri kendi özellikleri ile bağdaştırdıkları söylenebilir. Özel yetenekli öğrencilerin mühendislik algılarını belirlerken çiz-yazanlat tekniği kullanılmıştır. Bu kapsamda öğrencilerin mühendislik algılarını incelemek için çiz-yaz-anlat tekniğinin uygulanabilir ve alternatif bir teknik olduğu sonucuna da varılabilir. Tüm bu değerlendirmeler 1şı̆̆ında aşağıdaki önerilerde bulunulabilir:

- Mühendis olmaya aday özel yetenekli öğrenciler için özellikle BİLSEM'lerde, fen ve matematik öğretiminin mühendislik ve teknoloji alanları ile ilişkilendirilerek bütüncül bir şekilde verilmesi, mühendislik temalarını içerisinde barındıran bilim ve teknolojideki hızlı değişimlere paralel etkinliklerin tercih edilmesi önerilmektedir.

- Bilim ve teknolojide hızlı gelişme ve değişimlerin yaşandığı günümüzde, özel yetenekli öğrencilerin mühendislik algılarını zenginleştirmek ve algılarında olumlu değişimler sağlayabilmek için özellikle yeni ve gelecekte önem kazanacak olan mühendislik alanlarıyla ilgili olarak okullarda tanıtım posterleri oluşturulmalı, söz konusu öğrencilerin farklı alanlardaki mühendisler ile etkileşime girmeleri sağlanmalı ve bu öğrencilere uzman kişilerce bilgilendirmeler yapılmalıdır. 
- Özel yetenekli öğrencilerin, mühendisin cinsiyetine yönelik var olan algılarını değiştirmek ve özellikle kadın öğrencilerin meslek seçimlerinde mühendisliği bir seçenek olarak görmelerini sağlamak amacıyla alanında başarılı olmuş kadın mühendislerin de katılımıyla mesleki kariyer eğitimleri düzenlenebilir.

- Özel yetenekli öğrencilerin mesleki tercihlerine dönük stratejik planlamalar yapılmalı; popüler meslekler, gelecek kaygısı, maddi beklentiler, cinsiyetçi yaklaşımlar, çevrenin yanlış yönlendirmeleri gibi etkilerden korunup sahip oldukları ilgi ve yetenekleri doğrultusunda meslek tercihi yapabilmeleri için söz konusun öğrencilerin aileleri, BİLSEM ve BİLSEM dışında devam ettikleri okullar arasındaki eşgüdüm artırılmalı ve rehberlik çalışmaları yoğunlaştırılmalıdır.

- Bilimsel ve teknolojik açıdan araştırma ve üretimde öne çıkan yurt çapındaki sanayi kuruluşlarına geziler düzenlenerek özel yetenekli öğrencilerin mühendislik uygulamalarını yerinde incelemeleri sağlanmalıdır.

- Mühendislik uygulamalarının günlük yaşamın her alanında yer aldığının bilincinde olan özel yetenekli öğrenciler için BİLSEM'lerde belli zamanlarda mevcut ve olası dünya problemlerinden biri belirlenerek çeşitli iletişim kanalları ile farkındalık oluşturulmalı ve öğrencilerden probleme yönelik çözüm önerileri ve tasarım odaklı somut dönütler beklenmelidir.

- Özel yetenekli öğrencilerin, dünyada yaşanan ve yaşanabilecek olan çeşitli problemlere çözümler sunabilecek ulusal ve uluslararası çapta projelerde yer almaları desteklenmeli ve ilgili alandaki mühendislerin projelere danışmanlık yapması sağlanmalıdır.

- Bu çalışma, Doğu Anadolu'da yer alan bir BİLSEM'de farklı öğretim programlarında öğrenim gören 76 özel yetenekli öğrenci ile sınırlıdır. Çalışmanın farklı bölge ve okulları içine alacak şekilde genişletilmesi önerilmektedir. 


\section{Kaynakça/References}

Akaygun, S. ve Aslan-Tutak, F. (2016). STEM images revealing STEM conceptions of preservice chemistry and mathematics teachers. International Journal of Education in Mathematics, Science and Technology, 4(1), 56-71. doi:10.18404/ijemst.44833

Akbaş, M. ve Çetin, P. S. (2018). Üstün yetenekli öğrencilerin çeşitli sosyobilimsel konulara ilişkin argümantasyon kalitesinin ve informal düşünme becerisinin incelenmesi. Necatibey Ĕgitim Fakültesi Elektronik Fen ve Matematik Ĕgitimi Dergisi, 12(1), 339-360. doi:10.17522/balikesirnef.437794

Ataman, A. (2004). Üstün zekâlı ve üstün özel yetenekli çocuklar. M. R. Şirin, A. Kulaksızoğlu, A. E. Bilgili (Ed.), Üstün yetenekli çocuklar seçilmiş makaleler kitabı içinde. (ss. 155-168). İstanbul: Çocuk Vakfı.

Aydın, G., Saka, M. ve Guzey, S. (2018). Engineering knowledge level measurement scale for students in grades 4 through 8. Elementary Education Online, 17(2), 750-768 doi:10.17051/ilkonline.2018.419071

Balçın, M. D. ve Ergün, A. (2019). Altıncı sınıf öğrencilerinin gözünden havacılık ve uzay mühendisi. Pamukkale Üniversitesi Eğitim Fakültesi Dergisi, 45(45), 1-21. doi:10.9779/PUJE.2018.219

Balçın, M. D. ve Topaloğlu, M. Y. (2019). Okul dışı öğrenme ortamlarında ilkokul öğrencilerinin mühendislere ve bilim insanlarına yönelik algılarının incelenmesi. Sosyal Bilimler Araştırmaları Dergisi, 9(1), 157-170.

Benek, İ. ve Akçay, B. (2018). Hayal dünyamda STEM! Öğrencilerin STEM alanında yaptıkları çizimlerin incelenmesi. Journal of STEAM Education, 1(2), 79-107.

Bilen, K., Irkıçatal, Z. ve Ergin, S. (2014, Eylül). Ortaokul öğrencilerinin bilim insanı ve mühendis algıları. Sözel Bildiri, XI. Ulusal Fen Bilimleri ve Matematik Eğitimi Kongresi, Adana.

Brownlee, J. Curtis, E. Spooner-Lane, R., \& Feucht, F. (2017) Understanding children's epistemic beliefs in elementary education. Education 3-13-International Journal of Primary, Elementary and Early Years Education, 45(2), 191-208. doi:10.1080/03004279.2015.1069369

Bulut, E. ve Akçacı, T. (2017). Industry 4.0 and within the scope of innovation indicators analysis of Turkey. ASSAM International Refereed Journal, 4(7), 50-72.

Büyüköztürk Ş., Kılıç-Çakmak, E., Akgün, Ö. E., Karadeniz, Ş. ve Demirel, F. (2012). Bilimsel araştırma yöntemleri (13. baskı). Ankara: Pegem Akademi.

Campbell, C., Speldewinde, C., Howitt, C., \& MacDonald, A. (2018). STEM practice in the early years. Creative Education Journal Special Edition Preschool Education Research, 9(1), 11-25. doi:10.4236/ce.2018.91002

Christensen, L. B., Johnson, R. B., \& Turner, L. A. (2015). Araştırma yöntemleri. (A. Aypay, çev. ed.). Ankara: Anı Yayınc1lık.

Chubb, I. (2013). Science technology, engineering and mathematics in the national interest: A strategic approach. Canberra: Office of the Chief Scientist, Australian Government.

Cunnignham, C. M., Lachapelle, C., \& Lindgren-Streicher, A. (2005). Assessing elementary school students' conceptions of engineering and technology. Proceedings of the 2005 American Society for Engineering Education Annual Conference \& Exposition.

Çakmak, B., Bilen, K. ve Taner, M. S. (2019). Ortaokul öğrencilerinin mühendis ve mühendislik algıları. Anadolu Öğretmen Dergisi, 3(1), 32-43. doi:10.35346/aod.559599

Çetin, B, Y. ve Asiltürk, E. (2017). Ortaokul beşinci sınıf öğrencilerinin mühendislik imajları. The Journal of New Trends in Educational Sciences, 1(1), 55-66.

Çetinkaya, Ç. ve İnci, G. (2019). Üstün zekâlı ve yetenekli çocukların erken çocukluk döneminde tanılanmasında öğretmenlerin düşünceleri. Kastamonu Education Journal, 27(3), 959-968. doi:10.24106/kefdergi.2130

Çitil, M. ve Ataman, A. (2018). İlköğretim çağındaki üstün yetenekli öğrencilerin davranışsal özelliklerinin eğitim ortamlarına yansıması ve ortaya çıkabilecek sorunlar. Gazi Üniversitesi Ĕ̈itim Fakültesi Dergisi, $38(1), 185-231$.

Dinç, E. ve Üztemur, S. (2017). Investigating student teachers' conceptions of social studies through the multidimensional structure of the epistemological beliefs. Educational Sciences: Theory \& Practice, 17(6), 2093-2142. doi:10.12738/estp.2017.6.0429 
Diwan, P. (2017). Is Education 4.0 an imperative for success of 4th industrial revolution? Retrieved from https://medium.com/@ pdiwan/is-education-4-0-an-imperative-for-success-of-4th-industrial-revolution$50 \mathrm{c} 31451 \mathrm{e} 8 \mathrm{a} 4$

Egan, A., Maguire, R., \& Rooney, B. (2015). Exploring children's perception of creativity using the draw-writetell technique. The Irish Psychologist, 42(1), 11.

English, L. D., \& King, D. (2015). STEM learning through engineering design: Fourth-grade students' investigations in aerospace. International Journal of STEM Education, 2(14), 1-18. doi:10.1186/s40594015-0027-7

Ergun, A., \& Balcin, M.D. (2019). The perception of engineers by middle school students through drawings. Eurasian Journal of Educational Research, 83, 1-28, doi:10.14689/ejer.2019.83.1

Ergün, A. (2018). Türk ortaokul öğrencilerinin mühendislik ve teknoloji algıları: Sınıf düzeyi ve cinsiyetin etkisi. Journal of Human Sciences, 15(4), 2657-2673. doi:10.14687/jhs.v15i4.5260

Fan, S. C., \& Yu, K.C. (2015). How an integrative STEM curriculum can benefit students in engineering design practices. International Journal of Technology and Design Education, 27, 107-129. doi:10.1007/s10798015-9328-x

Fralick, B., Kearn, J., Thompson, S., \& Lyons, J. (2009). How middle schoolers draw engineers and scientists. Journal of Science Education and Technology, 18(1), 60-73. doi:10.1007/s10956-008-9133-3

Gülhan, F. ve Şahin, F. (2018). A comparative investigation of middle school 5th and 7th grade students' of perceptions on engineers and scientists. Necatibey Eğitim Fakültesi Elektronik Fen ve Matematik Eğitimi Dergisi, 12(1), 309-338. doi:10.17522/balikesirnef.437785

Hobbs, L., Cripps Clark, J., \& Plant, B. (2017). Successful students STEM program: Teacher learning through a multifacted vision for STEM education. In R. Jorgensen, \& K. Larkin (Eds.), STEM Education in the Junior Secondary (pp. 133-168). Singapore: Springer.

Karatas, F. O., Micklos, A., \& Bodner, G. M. (2011). Sixth-grade students' views of the nature of engineering and images of engineers. Journal of Science Education and Technology, 20(2), 123-135. doi:10.1007/s10956-010-9239-2

King, D., \& English, L. D. (2016). Engineering design in the primary school: Applying STEM concepts to build an optical instrument. International Journal of Science Education, 38(18), 2762-2794. doi:10.1080/09500693.2016.1262567

Knezek, G., Christensen, R., Tyler-Wood, T., \& Periathiruvadi, S. (2013). Impact of environmental power monitoring activities on middle school student perceptions of STEM. Science Education International, 24(1), 98-123.

Knight, M., \& Cunningham, C. (2004). Draw an engineer test (DAET): Development of a tool to investigate students' ideas about engineers and engineering. Paper presented at the ASEE Annual Conference and Exposition, Salt Lake City, UT.

Koyunlu Ünlü, Z. ve Dökme, İ. (2017). Özel yetenekli öğrencilerin FETEMM'in mühendisliği hakkındaki imajlar1. Trakya University Journal of Education Faculty, 7(1), 196-204.

Lamb, R., Akmal, T., \& Petrie, K. (2015). Development of a cognition-priming model describing learning in a STEM classroom. Journal of Research in Science Teaching, 52(3), 410-437. doi:10.1002/tea.21200

Lincoln, Y. S., \& Guba, E. G. (2013). The constructivist credo. California, CA: Left Coast Press.

Miles, M. B., \& Huberman, A. M. (1994), Qualitative data analysis: An expanded sourcebook. Sage, London.

Milli Eğitim Bakanlığı [MEB]. (2017). Çocuk gelişimi ve eğitimi. Üstün zekalılar ve özel yetenekliler. Ankara: MEB Yayınevi.

Milli Eğitim Bakanlı̆̆ı [MEB]. (2018). İlköğretim fen bilimleri dersi (3, 4, 5, 6, 7 ve 8. sinıflar) öğretim programı. Ankara: MEB Yayınevi.

National Research Council [NRC]. (2011). Successful K-12 STEM education: Identifying effective approaches in science, technology, engineering, and mathematics. Retrieved from http://www.stemreports.com/wpcontent/uploads/2011/06/NRC_STEM_2

National Research Council [NRC]. (2012). A framework for K-12 science education: Practices, crosscutting concepts, and core ideas. Washington, DC: National Academies Press. 
National Research Council [NRC]. (2013). Next Generation Science Standards: For States, By States. Washington, DC: The National Academies Press. doi:10.17226/18290.

Schreglmann, S. (2016). Türkiye'de üstün yetenekli öğrenciler ile ilgili yapılan yükseköğretim tezlerinin içerik analizi (2010-2015). Üstün Yetenekliler Eğitimi Araştırmaları Dergisi, 4(1), 14-26.

Schwab, K. (2016). Dördüncü sanayi devrimi. (Z. Dicleli, çev.). İstanbul: Optimist Yayıncılık.

Shenton, A. K. (2004). Strategies for ensuring trustworthiness in qualitative research projects. Education for Information, 22(2), 63-75.

Silver, A., \& Rushton, B. S. (2008). Primary-school children's attitudes towards science, engineering and technology and their images of scientists and engineers. Education 3-13-International Journal of Primary, Elementary and Early Years Education, 36(1), 51-67. doi:10.1080/03004270701576786

Stohlmann, M., Moore, T., \& Roehrig, G. (2012). Considerations for teaching integrated STEM education. Journal of Pre-College Engineering Education Research, 2(1), 28-34. doi:10.5703/1288284314653

Tavşancıl, E. ve Aslan, E. (2001). Sözel, yazılı ve diğer materyaller için içerik analizi ve uygulama örnekleri. İstanbul: Epsilon.

Timur, B. ve İnançlı, E. (2018). Fen bilimleri öğretmen ve öğretmen adaylarının STEM eğitimi hakkındaki görüşleri. Uluslararası Bilim ve Ë̆itim Dergisi, 1(1), 48-66.

Üztemur, S. ve Dinç, E. (2018). A student-centered approach to explore middle school students' epistemological beliefs: Draw-write-tell technique. Journal of History Culture and Art Research, 7(3), 566-592. doi:10.7596/taksad.v7i3.1579

Vasquez, J., Sneider, C., \& Comer, M. (2013). STEM lesson essentials, grades 3-8: Integrating science, technology, engineering, and mathematics. Portsmouth, NH: Heinemann.

Walker, M. (2001.) Engineering identities. British Journal of Sociology of Education, 22, 75-89.

Wendell, K. B., \& Rogers, C. (2013). Engineering design-based science, science content performance, and science attitudes in elementary school. Journal of Engineering Education, 102(4), 513-540. doi:10.1002/jee.20026

Yıldırım, A. ve Şimşek, H. (2013). Sosyal bilimlerde nitel araştırma yöntemleri (9. baskı), Ankara: Seçkin Yayıncilik.

Yıldırım, B. ve Selvi, M. (2018). Examination of the opinions of middle school students on stem practices. Journal of Social Sciences of Mus Alparslan University, 6(STEMES'18), 47-54. doi:10.18506/anemon.471037

Zhang, Y., \& Wildemuth, B. M. (2009). Qualitative analysis of content. In B. M. Wildemuth (Ed). Applications of social research methods to questions in information and library science (pp. 308-319). California: Libraries Unlimited. 